\title{
Overview and evaluation of the Indonesia's water resources management policies for food security
}

\author{
ANDI SETYO PAMBUDI \\ Directorate for Monitoring, Evaluating and Controlling Regional Development \\ Ministry of National Development Planning/ National Development Planning Agency (Bappenas) \\ Gedung Bappenas Lantai 9, Jl. H.R. Rasuna Said, Kuningan, Jakarta 12920, Indonesia
}

Corresponding author: andi.pambudi@bappenas.go.id

Submitted 28 July 2021; Accepted 26 August 2021

\begin{abstract}
Water and water resources must be maintained by their functions and benefits to meet the needs of all sectors and future generations. One important part of sustainable water resource management that is of considerable interest to the government is irrigation which aims to achieve food security. Food security in Indonesia Development in the field of food security and poverty alleviation in rural areas is one of the leading sectors in the nine national development priority agendas contained in "Nawa Cita". The development of food security in Indonesia faces many complex problems, such as irrigation infrastructures maintenance, regulations, land use change, population, policy implementation, coordination among stakeholders and also budget issues. The method in this study is a qualitative method through the literature review related to the management of water resources for food security in Indonesia. This paper seeks to evaluate the development irrigation policies as part of sustainable water management that supports food security in Indonesia. Literature sources are 5 main regulations, 5 papers and some government reports. To support increased food security, the direction of the Indonesian Government's policy in strengthening food security from the irrigated agricultural sector is realized through a strategy to increase production capacity and improve irrigation network services. The problem of the availability of irrigation water must be addressed quickly by upstream conservation, maximizing capacity through normalization of existing reservoirs, and continuing to build dams to have water storage containers that can accommodate planting season throughout planting.
\end{abstract}

\begin{abstract}
ABSTRAK
Air dan sumber daya air harus dijaga fungsi dan manfaatnya untuk memenuhi kebutuhan semua sektor dan generasi mendatang. Salah satu bagian penting dari pengelolaan sumber daya air berkelanjutan yang cukup menarik perhatian pemerintah adalah irigasi yang bertujuan untuk mencapai ketahanan pangan. Di Indonesia, pembangunan di bidang ketahanan pangan dan pengentasan kemiskinan di pedesaan merupakan salah satu sektor unggulan dalam sembilan agenda prioritas pembangunan nasional yang tertuang dalam "Nawa Cita". Pembangunan ketahanan pangan di Indonesia menghadapi banyak masalah yang kompleks, seperti pemeliharaan infrastruktur irigasi, regulasi, perubahan penggunaan lahan, kependudukan, implementasi kebijakan, koordinasi antar pemangku kepentingan dan juga masalah anggaran. Metode dalam penelitian ini adalah metode kualitatif melalui studi pustaka terkait pengelolaan sumber daya air untuk ketahanan pangan di Indonesia. Tulisan ini berupaya mengevaluasi kebijakan pembangunan irigasi sebagai bagian dari pengelolaan air berkelanjutan yang mendukung ketahanan pangan di Indonesia. Sumber literatur adalah lima peraturan utama, lima makalah dan beberapa laporan pemerintah. Untuk mendukung peningkatan ketahanan pangan, arah kebijakan Pemerintah Indonesia dalam memperkuat ketahanan pangan dari sektor pertanian beririgasi diwujudkan melalui strategi peningkatan kapasitas produksi dan peningkatan pelayanan jaringan irigasi. Masalah ketersediaan air irigasi harus segera diatasi dengan konservasi di wilayah hulu, memaksimalkan kapasitas melalui normalisasi waduk yang ada, dan terus membangun bendungan untuk memiliki wadah penampung air yang dapat mencukupi kebutuhan pasokan sepanjang musim tanam.
\end{abstract}

Keywords: food security, irrigation, policy, water

\section{INTRODUGTION}

Food is a vital need for humans with rice as a staple food for most of the world community. The demand for import of food from countries producing staple goods is increasing. Data from FAO shows that in 2017 world rice production reached 759.6 million tons or exceeded 0.6 percent from 2016. Most of the increase in rice yields concentrated in Asia, although the rate of production in the region was disrupted by disasters of floods and droughts. In Indonesia, food security is supported by the development of the agricultural sector as a focus in economic development. The government's attention is devoted to this sector given its role in creating high employment opportunities. Economic development by giving priority to the agricultural sector is a line of wisdom that began to be popular since the early sixties. Before that time (in the forties and fifties), agriculture was considered a passive sector in economic development, as a follower and supporter of a more active and more dynamic sector, namely the industrial sector. The 2020-2024 National Medium Term Development Plan (RPJMN), achievement of water, food and energy 
security is one of the national development priorities (GoI, 2020).

Water security determines food security and energy security (Bellfield et al., 2015). The main challenge in managing water resources in Indonesia is the increasing demand for water but with a relatively constant supply, and even in some cases it tends to decrease. This means that the competition for water is getting higher, while the need for water is absolute and cannot be delayed (Euler et al., 2018; Kindu et al., 2017; Bellfield et al., 2015). It needs to be regulated in such a way as to be able to meet the water needs of all parties, because failure or delay in meeting water needs will only cause other bigger problems. Especially for food security, the availability of water with proper and integrated management becomes a separate problem that requires special attention. In the next few years, the world to experience food shortages caused by excessive and uncontrolled water use. Contamination and damage to groundwater sources and irrigation are expected to result in a lack of grain such as rice and wheat (Tripathi \& Singal, 2019; Pasandaran \& Rosegrant, 1999).

Irrigated paddy fields have a very strategic position because most of the rice production is produced from this area, reaching an area of 6.7 million ha. The large reduction in this area will have a negative impact on national rice production. Rice fields have an important role in determining food security where $90 \%$ of rice consumed in Indonesia is self-produced and about $95 \%$ of this production is produced from paddy fields (GoI, 2020).

Indonesia has abundant water, but water management issues have an impact on unequal distribution of water between regions, water wastage, weak law enforcement and water pollution (Quincieu, 2015). It must be recognized that irrigation which is traditionally managed by the government is the most inefficient public sector with investment costs that are increasingly expensive and are characterized by transparency and public accountability that are less or nothing at all to their performance. Since the economic crisis, which reached its peak in 1998, damage to irrigation and irrigation networks has increased as a result of low operating and maintenance performance and inadequate rehabilitation funds. The approach to irrigation development in the past, which tended to be centralized and took over the role of the community in the management of irrigation infrastructure, led to increasing dependence on the provision of government funds and had an impact on decreasing community participation in the operation and maintenance of irrigation networks.

Water resources management reform in Indonesia which has been going on since 1997 in the form of a Water Sector Adjustment Program (WATSAOP) has a significant impact on the policies of the Indonesian Government (Quincieu, 2015). In this context, things to be achieved include; 1) preparation of a water source development policy framework; 2) preparation of the organizational framework and financing of river basin management; 3) institutional arrangements and implementation of water quality management and; 4) institutional arrangements and irrigation management arrangements.

In addition to a decentralization of authority reforms, the paradigm that is to be built is sustainability which is indicated by the existence of environmental insights that do not leave behind social and economic aspects. Water and water resources must be maintained by their functions and benefits to meet the needs of all sectors and future generations. One important part of sustainable water resource management that is of considerable interest to the government is irrigation which aims to achieve food security. Development in the field of food security and poverty alleviation in rural areas is one of the leading sectors in the nine national development priority agendas contained in Nawa Cita (GoI, 2014). To support increased food security, the direction of the Indonesian Government's policy in strengthening food security from the irrigated agricultural sector is realized through a strategy to increase production capacity and improve irrigation network services. This paper seeks to evaluate irrigation development policies as part of sustainable water resource management that supports food security in Indonesia. Also, based on the results of the evaluation, recommendations for improvement in planning water resources are needed for future food security.

\section{METHODS}

This paper seeks to examine the condition of irrigations, water, food security and its problems based on literature studies from previous researchers, especially related to implementation of government policies. Many variables of government policies problems such as aspect of regulation, and technical implementation aspect can reflect water resources condition to support food security in Indonesia (Cao et al., 2020; Tripathy \& Singal, 2019; Pambudi, 2019). Among these variables, there are several dominant ones. The method used in this study is a qualitative approach through the study of literature related to the management of water resources for food security in Indonesia. This paper seeks to evaluate irrigation policies as part of sustainable water management that supports food security in Indonesia. Literature sources are 5 main regulations, 5 papers and 3 government reports. The results of the study will provide recommendations based on scientific theories and existing regulations, budget and technical aspect to support sustainable food and water security in Indonesia. 


\section{RESULTS AND DISGUSSION}

Water problems are the problem of ecological balance related to environmental carrying capacity (Pambudi, 2019; Common \& Stagl, 2005; Miller \& Spoolman, 2015). Ecology is always related to ecosystems, including biotic and abiotic components. Ecology in relation to humans involves economic and environmental factors in an equally important extent (Bellfield et al., 2016; Watson et al., 2014; Common \& Stagl 2005).

Food security improvement has been on Indonesia's development national priority for decades (Arif et al., 2020; Bellfield, 2016). Almost every area of food security is covered by Government action plans and policies, although in some cases overlapping. To identify what recommendations will be given in the food and water security, it is necessary to study regulations related to food and water security in Indonesia. There are 5 big regulations related to water resources. Some of the regulations are: a) Basic Law Year 1945 Article 5 Paragraph (2) and Article 33 Paragraph (3) ; b) Law Number 17 Year 2019 about Water Resources; c) Law Number 23 Year 2014 about Local Government; d) Law Number 18 Year 2012 about Food; and; e) Government Regulation No. 37 Year 2012 about Watershed Management.

Food security is the fulfillment of human needs related to sufficient, diverse, safe and affordable food (in terms of quality and quantity). (Arif et al., 2020). The definition of "food security" in the Law Number 18 Year 2012 about Food includes the "individual" and "appropriate religious belief" as well as the "culture" of the nation (GoI, 2012a). Those can be assumed as an "enrichment scope" of the previous definition in the Law Number 7 Year 1996 about Food. It was noted that the definition of "food security" in the Law Number 18 Year 2012 related to Food is substantially in line with the definition of Food and Agriculture Organization or FAO in which "food security exists when all people, at all times, have physical and economic access to sufficient safe and nutritious food that meets their dietary needs and food preferences for an active and healthy life."

Many studies show that the environment will be greatly affected when there are human activities that are not in accordance with conservation principles $(\mathrm{Li}$ et al., 2018). In a broader scope, the problem of coordination and synergy between sectors and regions in watershed management is also a serious threat to environmental problems. (Pambudi, 2019; Asdak, 2006). Apart from that, neglecting the contribution and role of the community is something that must be abandoned if the goal of development is to be more sustainable. For Indonesia, the problem of watershed management is very influential on the condition of water resources in general, which is spread in almost all major islands (Bappenas, 2015).

The picture shows that the problem of water resources in relation to watersheds is related to water quality, quantity, continuity and accessibility (Chandler et al., 2004). Some areas in Indonesia that still have good watershed conditions in general also face a few problems of crises in the quality and quantity of water resources, such as Papua and Kalimantan. However, these areas still face water accessibility problems. This is different from the areas of Java, Bali and Sumatra which have good access to water, but face problems of water availability and quality (Bappenas, 2015)

The difficulty of the availability of irrigation water hinders the government's target to achieve food security.

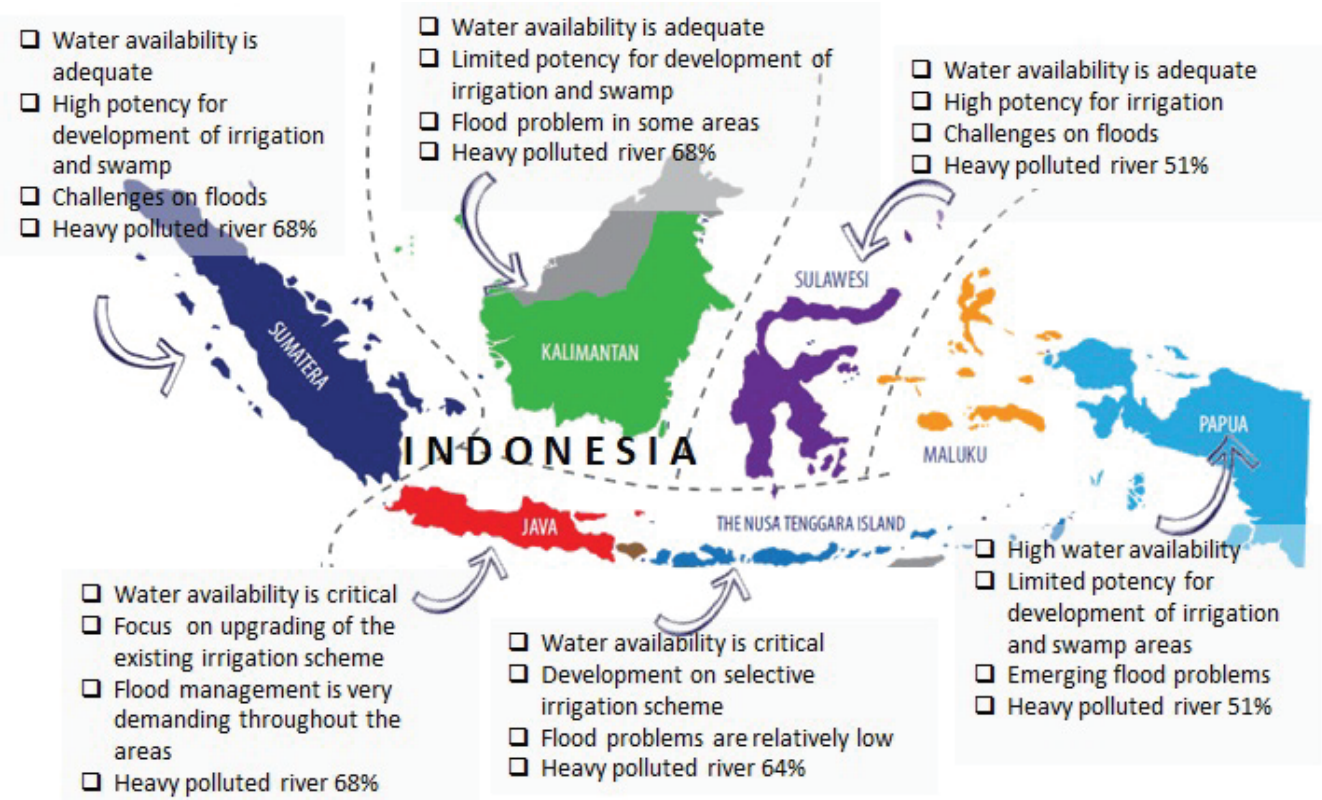

Figure 1. General problems of water resources in the Indonesian Islands region 
This condition is exacerbated by the dependence of the food sector fulfilled from Java, even though the water balance conditions have shown that conditions are no longer ideal. The government has a target of 3 (three) planting times to meet food needs, especially rice, domestically and reduce the volume of imports. Sufficient irrigation water can only be achieved if water source problems are upstream, maintenance of irrigation facilities from factors that can reduce water capacity (volume) such as sedimentation, and the construction of new weirs and reservoirs to collect water can be immediately completed.

Irrigation services are an important aspect of an agrarian country such as Indonesia. Good irrigation services will not only improve welfare for farmers' groups, but can also raise the nation's degree with self-sufficiency. What is currently found is that irrigation services have not been carried out optimally as indicated by the availability of water to drain agricultural land.

The availability of water is the main problem of irrigation and is a problem that arises every year, especially in the dry season. The problem of lack of water generally starts to occur during the Planting Period II (dry season) until it enters the rainy season. The severity of water shortages in each region may vary, but generally it cannot meet the needs for agricultural irrigation or even completely dry out. This problem occurs in each area observed. The decreasing availability of water has resulted in water that can be accommodated and distributed for agricultural irrigation increasingly limited.

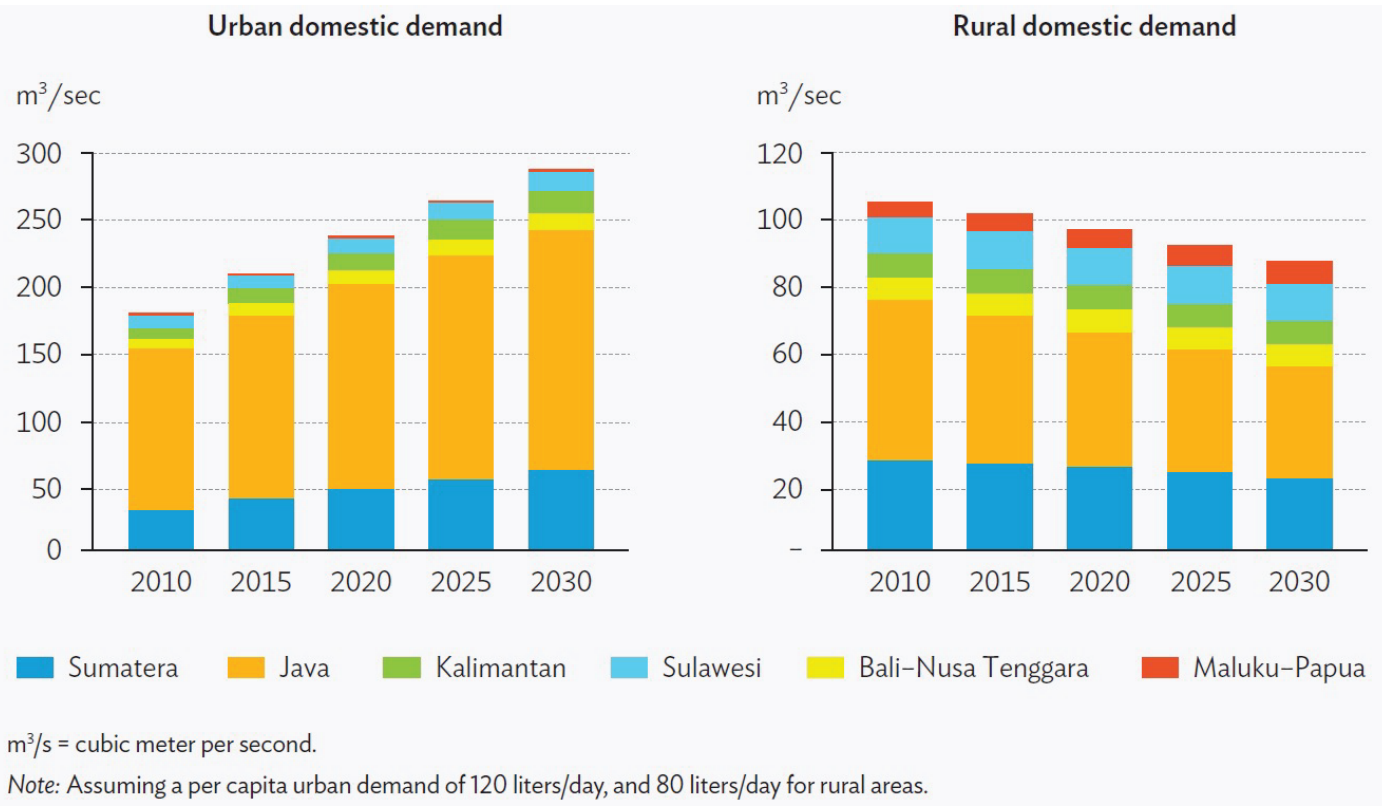

Figure 2. Predicted urban and rural domestic water demand in Indonesia

Source: Asian Development Bank (2016)

\section{Problems with Availability of Raw Water}

Food is the most important basic human need and its fulfillment is part of human rights guaranteed in the Constitution 1945 (Undang-undang Dasar 1945) of the Republic of Indonesia as a basic component to realize quality human resources (GoI, 2012a; GoI, 1945). Food and agriculture in Indonesia require good irrigation. The first problem related to the availability of water for irrigation is the source of water (Pambudi, 2019; Idris, 2019). Water sources are natural and / or artificial water containers or places which are located on, above or below the surface of the soil. Environmental damage upstream has reduced water supply. The occurrence of environmental damage upstream due to various activities that damage the environment, which causes a decrease in the carrying capacity of the environment for the existence and sustainability of water sources.
Environmental damage, especially the reduction of trees (forests) that are getting worse lately, causes rainwater to not be retained by the environment and becomes a water reserve for the dry season, but is directly channeled downstream to the sea.

Some activities that are identified as damaging the environment of water sources are based on field data, including logging or forest function conversion and group C mining activities (Azadi et al., 2018). Water shortages in the dry season are indicators of the absence of real and sustained efforts by environmental agencies to safeguard and protect sources water. Also related to the excavation of class $\mathrm{C}$ mines, it has not been carried out with due regard to environmental conservation so that it affects the sustainability of spring water sources.

Water supply does not increase the number of interested parties. The availability of water for irrigation 
Table 1. Literature review related to water resources / food security

\begin{tabular}{|c|c|c|c|c|c|c|}
\hline No & Author & Year & Title & Summary & $\begin{array}{l}\text { Digital Object } \\
\text { Identifier }\end{array}$ & Analysis Result \\
\hline 1 & Andi Setyo Pambudi & 2019 & $\begin{array}{l}\text { Watershed Management in } \\
\text { Indonesia : A Regulation, } \\
\text { Institution, and Policy } \\
\text { Review. }\end{array}$ & $\begin{array}{l}\text { Some sectoral regulations and } \\
\text { policies in Indonesia are not } \\
\text { aligned with ideal watershed } \\
\text { management objectives. This has } \\
\text { an impact on the condition of } \\
\text { water resources. The problem of } \\
\text { integration is still the most } \\
\text { difficult part in terms of the } \\
\text { number of agencies and } \\
\text { overlapping policies that are } \\
\text { driven by the goals of achieving } \\
\text { the targets of each sector. }\end{array}$ & $\begin{array}{l}\text { https://doi.org/10.36574/ } \\
\text { jpp.v3i2.74. }\end{array}$ & \multirow{5}{*}{$\begin{array}{l}\text { Evaluation of the } \\
\text { indonesia's water } \\
\text { resources management } \\
\text { policies to support food } \\
\text { security related to } \\
\text { problems with availability } \\
\text { of raw water, problems } \\
\text { with infrastructure and } \\
\text { governance, issues of } \\
\text { interference with other } \\
\text { parties and } \\
\text { land use change } \\
\text { problems. }\end{array}$} \\
\hline 2 & $\begin{array}{l}\text { R.F. Lubis, R. Delinom, } \\
\text { S.Martosuparno, \& H. } \\
\text { Bakti }\end{array}$ & 2018 & $\begin{array}{l}\text { Water-Food Nexus in } \\
\text { Citarum Watershed, } \\
\text { Indonesia. }\end{array}$ & $\begin{array}{l}\text { The nexus concept, namely the } \\
\text { linkage of water, food and } \\
\text { energy, has not been fully } \\
\text { effective at the site level. This is } \\
\text { due to the problem of sectoral } \\
\text { egos, overlapping regulations } \\
\text { and also problems of } \\
\text { understanding differences level } \\
\text { due which caused by lack of } \\
\text { socialization. }\end{array}$ & $\begin{array}{l}\text { doi:10.1088/1755- } \\
\text { 1315/118/1/012023 }\end{array}$ & \\
\hline 3 & Mohamad Ali Fulazzaky & 2014 & $\begin{array}{l}\text { Challenges of Integrated } \\
\text { Water Resources } \\
\text { Management in Indonesia. }\end{array}$ & $\begin{array}{l}\text { Indonesia has several problems } \\
\text { about water resources, such as } \\
\text { vailibility of raw water, drought, } \\
\text { flood, land use change, } \\
\text { stakeholder;s coordination, lack } \\
\text { of adequate water storage and } \\
\text { climate change }\end{array}$ & doi:10.3390/w6072000 & \\
\hline 4 & $\begin{array}{l}\text { Hidayat Pawitan and } \\
\text { Gadis S. Haryani }\end{array}$ & 2011 & $\begin{array}{l}\text { Water resources, } \\
\text { sustainability and societal } \\
\text { livelihoods in Indonesia }\end{array}$ & $\begin{array}{l}\text { The availability of water } \\
\text { resources related to quality and } \\
\text { quantity affects the income of the } \\
\text { Indonesian people, whether } \\
\text { related to forestry, agriculture } \\
\text { and other fields of work. These } \\
\text { problems are caused by land use } \\
\text { and land cover change, } \\
\text { decreased of river debit, water } \\
\text { pollution, and overlapping } \\
\text { natural resources regulations that } \\
\text { have an impact on policy } \\
\text { implementation }\end{array}$ & $\begin{array}{l}\text { doi:10.2478/v 10104-01 1- } \\
0050-3\end{array}$ & \\
\hline 5 & S. Soenarno & 1993 & $\begin{array}{l}\text { Is Irrigation Sustainable? } \\
\text { The Indonesian Perspective. }\end{array}$ & \multicolumn{2}{|c|}{$\begin{array}{l}\text { Indonesia's irrigation policies are doi:10.4296/cwrj1803281 } \\
\text { not consider sustainabily aspect, } \\
\text { such as related to environment } \\
\text { protection, pollution, } \\
\text { deterioration of the catchment } \\
\text { area, and mitigation of } \\
\text { population growth }\end{array}$} & \\
\hline
\end{tabular}

is also influenced by the number of parties interested in water. An example is in Maros Regency, where water from the Bantimurung River cannot meet the needs of irrigation because the PDAM also uses the same water source. Besides that, Bantimurung River water is also used for industrial activities for private companies, namely PT. Bossowa Semen. The Lekopancing Dam has been dominated to meet drinking water needs (PDAM) in the city of Makassar, while agricultural irrigation in
Maros Regency only gets its abundant water, ie if the excess from PDAM water use. The number of parties interested in water has an impact on availability. As a result, in the dry season in Bendung Batubassi (D.I. Bantimurung) there is still water, but it is not sufficient. This results in insufficient water for planting plans, especially in the dry season, so that rice fields can only be planted once (Ombudsman, 2016). 


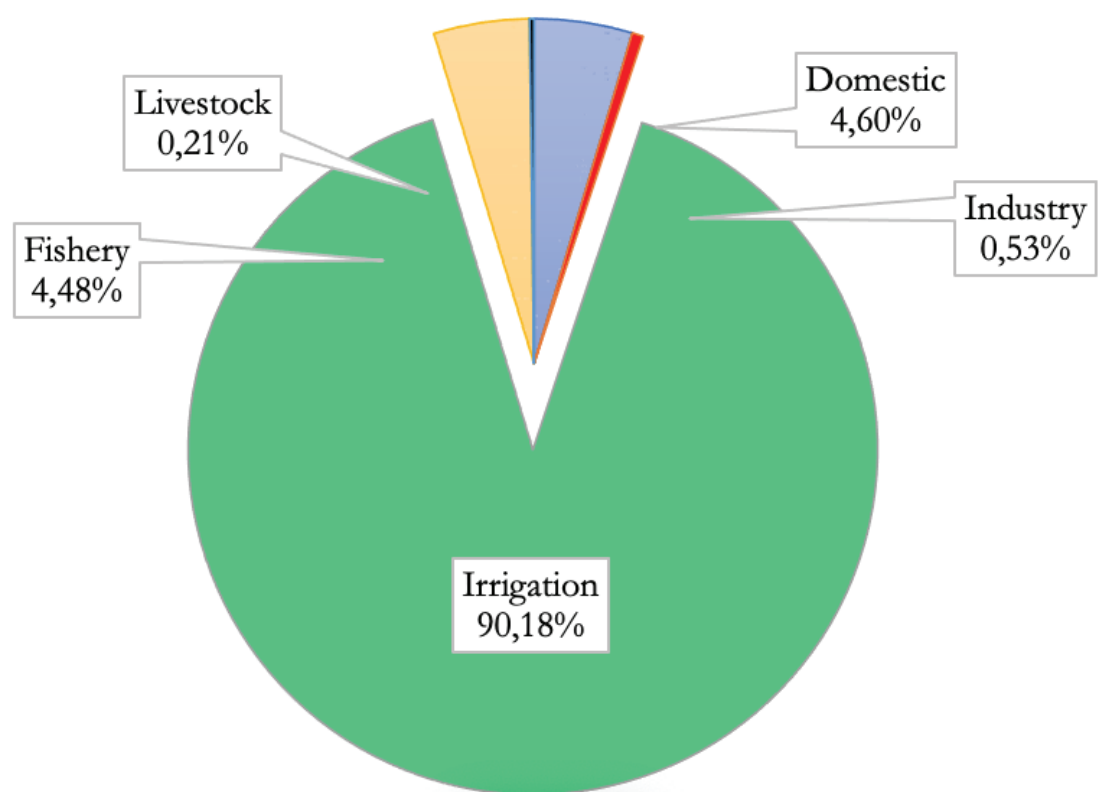

Figure 3. Domination of irrigation for water usage of Indonesia's surface water

Source: Idris (2019)

\section{Problems with Infrastructure and Governance}

The second problem relates to the availability of irrigation water and management of weirs and water collection/ collection containers in the form of dams and reservoirs. Some things that need attention, among others: Dam and reservoirs that are in good condition continue to decline while the need increases. Some areas that are potential for agricultural businesses, do not have adequate natural water sources, so they require water sources in the form of reservoirs. One obvious example is in Indramayu District, which is the largest rice-producing area in West Java Province, does not have adequate water storage. Cipancuh Reservoir in this area with an area of $700 \mathrm{Ha}$ can only serve during Planting Period I (rainy season) due to the absence of water supply other than rainwater and the condition of the reservoir experiencing severe siltation. Even if the reservoir is optimized it can irrigate an area of 6,314 ha of rice fields. Whereas the development plan of the Cipanas Dam has yet to be realized. At present the Government is intensifying the construction of new reservoirs. In 2015, the Government built 13 (thirteen) reservoirs namely Keureto Reservoir in Aceh, Seigong Reservoir in Riau Islands, Karian Reservoir in Banten, Logung Reservoir in Central Java, Telaga Waja Reservoir in Bali, Tapin Reservoir in South Kalimantan, Passeloreng Reservoir in South Sulawesi, Lolak Reservoir in North Sulawesi, Raknamo Reservoir in NTT, Rotiklod Reservoir in NTT, Tanju Reservoir in NTB, Mila Reservoir in NTB, and Bintang Bano Reservoir in NTB. However, it is also important to revitalize existing reservoirs but have not provided adequate benefits, such as the Cipancuh Reservoir in Indramayu Regency (Ombudsman, 2016)
Management of dams and reservoirs in several places has not been found to be optimal. Sedimentation found in several weirs was observed as an indicator that the dam could not accommodate water optimally. So that when the dry season arrives, the water in the dam shrinks in a short time because it does not accommodate the volume optimally.

One of the considerations in Law 17 of 2019 concerning Water Resources states that in the face of an imbalance between the decreasing availability of water and the increasing demand for water, water resources need to be managed by paying attention to social, environmental and economic functions in harmony to create synergy (GoI, 2019). Furthermore, this law try to support inter-regional, inter-sectoral and intergenerational integration in order to meet people's needs for water.

\section{Issues of Interference with Other Parties}

The existence of tug-of-war interests in the use of weirs for irrigation purposes and other interests need attention. One interesting example is the use of water in Lekopancing Dam which is monopolized by PDAM Makassar City, while agricultural irrigation can only be used when PDAM needs have been met. In fact, the operation and maintenance of the Lekopancing Dam was still carried out by officers under the Pompengan-Jeneberang River Basin.

Given the many parties that have an interest in water, the mechanism of water management by involving many interests must be a serious concern of the Government. So far, the pattern built by the Government is a pattern of management cooperation, both between the Central 


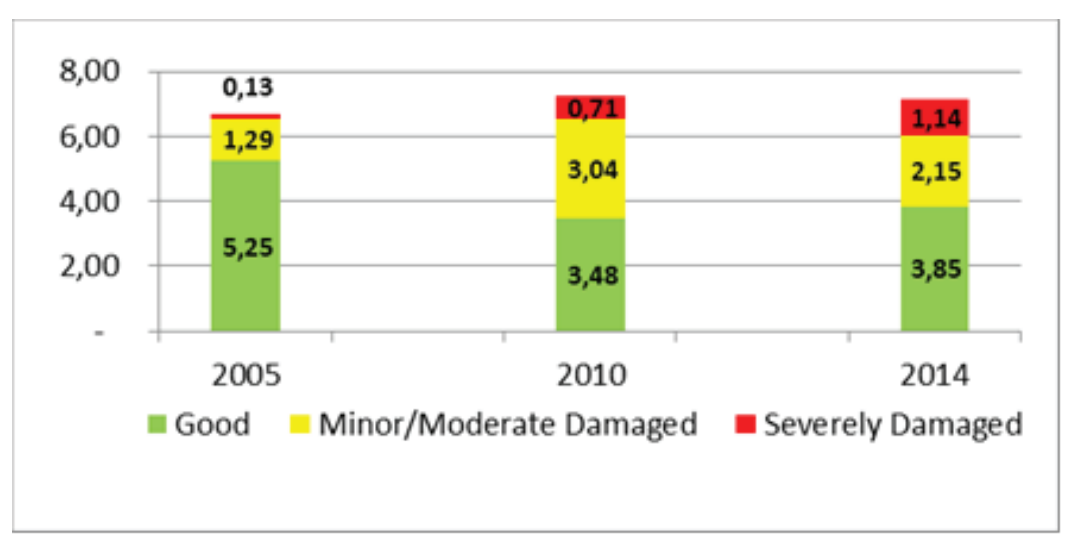

Figure 4. Irrigation infrastructure change in Indonesia (Million Ha)

Source: Idris (2019)

Government and the Regional Government, as well as with business entities. One of the things that need to be considered to build such cooperation is to uphold the principle that such cooperation must not interfere, put aside, let alone negate the people's right to water and be carried out in a participatory and accountable manner.

\section{Land Use Change Problems}

Land conversion that is not balanced with good conservation efforts affects the carrying capacity of the land towards environmental resilience (Cumming, 2016; Bonell \& Bruijnzeel, 2005) . Land-use change can also be interpreted as a change for other uses because of factors such as increasing population needs and increasing demands for a better quality of life. One of the effects of the conversion of paddy fields that are often in the spotlight of the wider community is the disruption of food security. In this connection the impact of the conversion of paddy fields to food problems is more detrimental than the impact of other factors such as drought, floods, and pest/ disease attacks. In the event of droughts, floods and pest / disease attacks, the problem of food caused is temporary, meaning that food problems only arise when the event occurs. However, in the event of land conversion, the problem of food generated is permanent or it will still be felt in the long term even though land conversion has not occurred again.

Regional government regulations greatly impact forest rehabilitation efforts through Forest management Units $(\mathrm{KPH})$ as a result of land use change. In the forestry sector, the regional government law brings about significant changes in forest management processes including forest management, with consequences for institutional arrangements (organization, human resources, infrastructure, budget) and regulatory authority (GoI, 2014b).

Mahaswari et al., 2016 said that the population growth rate which is still high and concentrated in certain areas causes the conversion of cultivated land to non-cultivated land such as road surfaces to be very difficult to control, and even many land uses exceed their carrying capacity. Deforestation, cultivation of food crops on steep slopes without adequate soil and water conservation are just a few illustrations of the causes of damage to the watershed hydrological system. The damage is characterized by a decrease in the watershed's ability to absorb, store and distribute rainwater during the rainy season. As a result, the addition of recharge in the rainy season is very limited so that the water supply in the dry season is low.

Vegetative conservation of water resources embodied in forest and land rehabilitation policies for restoration of critical land in forest management units $(\mathrm{KPH})$ and watersheds (GoI, 2014a; GoI, 2012b). The above efforts will still face challenges related to the rights and status of critical lands to be planted. In addition, there are still other challenges related to not optimal control of space utilization in the watershed. However, the rate of deforestation in forest areas was successfully reduced. The area of forest and burned land has also been reduced significantly through effective countermeasures. In its development, currently the watershed tends to experience a lot of damage and quality degradation.

\section{GONGLUSION}

The big vision for self-sufficiency in food is not an impossible thing to happen if the government is serious to solve the issue regarding the availability of water for agricultural land. In order to realize the government's target of achieving food security, the problem of the availability of irrigation water must be addressed quickly by upstream conservation, maximizing capacity through normalization of existing reservoirs, and continuing to build dams to have water storage containers that can accommodate planting season throughout planting.

\section{REGOMMENDATIONS}

1. Conduct Environmental Conservation in Upper Watershed. The carrying capacity of the upstream watershed is very important in its role in water availability. Well-maintained upstream watershed 
will be able to store and provide a source of water that can be used until the dry season. However, forest destruction and the environment reduce the carrying capacity. Therefore, efforts are needed to normalize the upstream and increase its carrying capacity by carrying out conservation.

2. Normalization of Dam. One of the problems with the lack of water availability for planting is the lack of attention to the condition of the dam / reservoir. The amount of sedimentation that reduces the capacity of existing dams / reservoirs is an example of the frequent impacts. Rarely do activities to clean the dam / sedung from sedimentation cause the volume of water that can be accommodated by the dam / reservoir is reduced, besides also because leakage gates and canals and so on. The available water is not optimal. Therefore, dams / ponds need to be immediately and routinely cleaned and renovated. The sedimentation is dredged and the leak is patched so that it can reach its maximum potential in accommodating water to be distributed through irrigation channels to the existing agricultural land.

3. Extensification of Dam/ Reservoir. In addition to improving the quality of the upstream environment and increasing the maintenance of existing facilities, the construction of dams / reservoirs / reservoirs to accommodate and provide irrigation water needs to be added, especially in areas that become national rice barns. This policy will support efforts to provide water for irrigation. The availability of water in the dry season cannot meet irrigation needs, so water services for agriculture in the dry season cannot be carried out optimally. This is partly due to reduced water resources in the upstream due to environmental damage, the ability of weirs to maintain water volume is not optimal due to sedimentation, and the lack of raw water due to the lack of dams and reservoirs. In some areas, irrigation water must be shared for agriculture, PDAMs and even private companies.

4. Building a media of technology. Building a media of technology that can monitor the condition of dams / reservoirs and predict and anticipate irrigation water needs quickly. The media is designed to be participatory and user friendly, especially for water officials in the field.

5. Implementing law enforcement on violations of protected water sources for irrigation. The development of a coordination system related to irrigation requires clear rules regarding law enforcement, both in terms of water regulation, and social justice related to community rights. Regulations related to soil and water conservation as well as water resources are also suggested to be implemented after coordinating with related sectors.

6. Acceleration of supplying sufficient, safe and affordable bulk water from source to rice field or other food land. Some recommendation that can be implemented are: a) Optimizing water resource from dam; b) Repairing irrigation infrastructures, and distribution system; c) Developing modern distribution network for iririgation community ;d) Developing innovative business/management model for regional water provision (regional water authority); e) Institutional and regulation set-up for irrigation management; f) Improving community awareness on and involvement in water-saving behaviour

\section{AGKNOWLEDGEMENTS}

Thanks are due to Directorate of Monitoring, Evaluating and Controlling Regional Development Bappenas for providing the opportunity, knowledge and facility support. Thanks are due to my current director Agustin Arry Yanna, SS, MA; my former director Ir. Basah Hernowo, MA and Ir. Wahyuningsih Darajati, M.Sc; Sri Hidayati, S.Si, M.Han; Desak Annisa Cahya Putri; and all staffs of Directorate of Monitoring, Evaluating and Controlling Regional Development Bappenas for useful comments on the earlier drafts of the paper.

\section{REFERENGES}

Arif, S., Isdijoso, W., Fatah A.R., \& Tamyis, A.R. (2020). Strategic Review of Food Security and Nutrition in Indonesia: 2019-2020 Update. Jakarta: The SMERU Research Institute. ISBN 978-623-7492-42-9 [PDF]

Asdak, Chay. (2010). Hidrologi dan Pengelolaan Daerah Aliran Sungai. Edisi Kelima (Revisi). Yogyakarta: Gadjah Mada University Press.

Asdak, Chay. (2006). Pengelolaan DAS Berbasis Masyarakat pada Wilayah Lintas Batas Administrasi. Makalah, disampaikan pada rapat koordinasi pengembangan kerjasama wilayah perbatasan bidang kehutanan. Bandung.

Asian Development Bank. (2016). Indonesia Country Water Assesment. ISBN 978-92-9257-360-7 (Print), 978-92-9257-361-4 (e-ISBN) Publication Stock No. RPT167988. Philippines: ADB

Azadi, H., Keramati, P., Taheri, F., Rafiaani, P., Teklemariam, D., Gebrehiwot, K., ... Witlox, F. (2018). Agricultural land conversion: Reviewing drought impacts and coping strategies. International Journal of Disaster Risk Reduction, 31, 184-195. doi:10.1016/j.ijdrr.2018.05.003

Bappenas. (2015). Kajian Pengaruh Kebijakan Konservasi Sumber Daya Air di dalam DAS Terhadap Sektor Kehutanan dan Sektor lainnya. Jakarta: Bappenas. 
Bellfield, B., Leggett, M., Trivedi, M., Pareira, J., Gangga, A. (2016). How Can Indonesia Achieve Water, Energy and Food Security? Jakarta: WCS and Global Canopy Programme.

Cao, F., Lu, Y., Dong, Li, X. (2020). Evaluation of natural support capacity of water resources using principal component analysis method: a case study of Fuyang district, China. Appl Water Sci 10, 192 (2020).

https://doi.org/10.1007/s13201-020-1174-7

Common, M. \& Stagl, S. (2005). Ecological Economic: An Introduction. New York: Cambridge University Press.

Bonell, M., \& Bruijnzeel, L.A. (2005). Forest, Water, and People in the Humid Tropics: Past, Present, and Future Hydrological Research for Integrated Land and Water Management. United Kingdom: Cambridge University Press.

Chandler, Fiona, J.C. \& Suyanto. (2004). Recognizing and rewarding the provision of watershed services. World Agroforestry Centre (ICRAF Southeast Asia).

Common, M. \& Stagl, S. (2005). Ecological Economic: An Introduction. New York: Cambridge University Press.

Cumming, Graeme S.(2016). The Relevance and Resilience Of Protected Areas in the Anthropocene. Anthropocene https://doi.org/10.1016/j.ancene.2016.03.003

Euler, J., \& Heldt, S. (2018). From information to participation and self-organization: Visions for European river basin management. Science of The Total Environment, 621, 905-914. doi:10.1016/j.scitotenv.2017.11.072

Fulazzaky, M. (2014). Challenges of Integrated Water Resources Management in Indonesia. Water, 6(7), 2000-2020. doi:10.3390/w6072000

GoI. (2020). Peraturan Presiden Nomor 18 Tahun 2020 tentang Rencana Pembangunan Jangka Menengah Nasional 2020 - 2024 (Presidential Regulation Number 18 Year 2020) about Mid-Term Development Plan 2020 - 2024).

GoI. (2019). Undang-undang Nomor 17 Tahun 2019 tentang Sumber Daya Air. Jakarta: Pemerintah Indonesia

GoI. (2014a). Undang-undang Nomor 37 Tahun 2014 tentang Konservasi Tanah dan Air (Law Number 37 Year 2014 about Soil and Water Conservation). Jakarta: Pemerintah Indonesia

GoI. (2014b). Undang-undang Nomor 23 Tahun 2014 tentang Pemerintahan Daerah (Law Number 23 Year 2014 about Regional Government). Jakarta: Pemerintah Indonesia

GoI. (2012a). Undang-undang Nomor 18 Tahun 2012 tentang Pangan Daerah (Law Number 18 Year 2012 about Food). Jakarta: Pemerintah Indonesia

GoI. (2012b). Peraturan Pemerintah No. 37 Tahun 2012 tentang Pengelolaan DAS (Government Regulation Number 37 Year 2012 about Watershed Management). Jakarta: Pemerintah Indonesia
GoI. (1945). Undang-undang Dasar 1945 (Constitution 1945). Jakarta: Pemerintah Indonesia

Idris, Abdul Malik Sadat. (2019). Water Management in Indonesia. Presented to ASEAN Workshop on Water Management and Climate Change towards Asia's Water-Energy-Food Nexus and SDGs,Bangkok, January $23^{\text {rd }}$, 2019

Li, R., Zheng, H., Lv, S., Liao, W., \& Lu, F. (2018). Development and evaluation of a new index to assess hydrologic regulating service at sub-watershed scale. Ecological Indicators, 86, 9-17. doi:10.1016/j.ecolind.2017.12.023

Lubis, R. F., Delinom, R., Martosuparno, S., \& Bakti, H. (2018). Water-Food Nexus in Citarum Watershed, Indonesia. IOP Conference Series: Earth and Environmental Science, 118, 012023. doi:10.1088/1755-1315/118/1/012023

Maheshwari, B., Singh, V.P., \& Thoradeniya, B. (2016). Balanced Urban Development: Options and Strategies for Liveable Cities. Water Science and Technology Library. ISBN 978-3-319-28110-0 ISBN 978-3-319-28112-4 (eBook). DOI 10.1007/978-3-319-28112-4

Miller, G.T. \& S.E. Spoolman. (2015). Living in the Environment : Concepts, Connections and Solutions. Seventeenth edition. Brooks/Cole, Belmont, CA (USA)

Ombudsman RI. (2016). Pelayanan Irigasi "Sedia Air Sebelum Swasembada". Ombudsman Brief No.1 Tahun 2016.

Pambudi, Andi Setyo. (2019). Watershed Management in Indonesia: A Regulation, Institution, and Policy Review. The Indonesian Fournal of Development Planning, 3(2), 185-202. ISSN: 2654-2625 (Online) ISSN: 2598-0807 (Print). https://doi.org/10.36574/jpp.v3i2.74.

Pasandaran, E., \& Rosegrant, M.W. (1999). Irrigation investment in indonesia: trend and determinants, dalam I. Wayan Rusastra, dkk. Penyunting. Dinamika inovasi sosial ekonomi dan kelembagaan pertanian. Buku I. Pusat Penelitian Sosial Ekonomi Pertanian, Badan Penelitian dan Pengembangan Pertanian, Departemen Pertanian, hal 56-71.

Pawitan, H., \& Haryani, G. S. (2011). Water resources, sustainability and societal livelihoods in Indonesia. Ecohydrology ङ Hydrobiology, 11(3-4), 231-243. doi:10.2478/v10104-0110050-3

Quincieu, Eric. (2015). Summary of Indonesia's Agriculture, Natural Resources, and Environment Sector Assessment. Asian Development Bank

Soenarno, S. (1993). Is Irrigation Sustainable? The Indonesian Perspective. Canadian Water Resources fournal, 18(3), 281-290. doi:10.4296/cwrj1803281 
Tripathi, M, \& Singal, S.K.(2019). Use of principal component analysis for parameter selection for development of a novel water quality index: a case study of river Ganga India. Ecol Indic 96:430-436. https://doi.org/10.1016/ j.ecolind.2018.09.025
Watson, J. E. M., Dudley, N., Segan, D. B., \& Hockings, M. (2014). The performance and potential of protected areas. Nature, 515(7525), 67-73. doi:10.1038/nature13947 